\title{
Aquaculture Base Group (ABG) Sebagai Upaya Pengembangan Ekonomi Perikanan Berkelanjutan
}

\section{Aquaculture Base Group (ABG) as an Effort to Develop a Sustainable Fisheries Economy}

\author{
Syavin Pristiwayuning Rachmadhany ${ }^{1 *}$, Rusdi Abdat ${ }^{1}$, Ahmad Rido'i Yuda Prayogi ${ }^{2}$ \\ ${ }^{1}$ Department of Fish Health Management and Aquaculture, Universitas Airlangga, Kampus C, Jalan \\ Mulyorejo, Surabaya, Jawa Timur 60115, Indonesia. \\ ${ }^{2}$ Department of Occupational Health and Safety, Public Health Faculty, Airlangga University, 60115, \\ Surabaya, East Java, Indonesia. \\ *Corresponding author: syavin.pristiwayuning.rachmadhany-2018@fpk.unair.ac.id
}

Submitted: 22 June 2021 Revised: 08 July 2021 Accepted: 16 July 2021 Publish: 31 July 2021

\begin{abstract}
Abstrak
Indonesia memiliki potensi yang sangat besar di bidang perikanan, hal ini dikarenakan sekitar 70\% wilayahnya merupakan lautan dan negara kepulauan. Budidaya udang di Indonesia merupakan budidaya yang banyak dilakukan oleh masyarakat Indonesia. Hal ini dikarenakan udang merupakan komoditas perikanan yang memiliki permintaan tertinggi. Aquaculture Base Group (ABG) bertujuan untuk memanajemen masyarakat yang semulanya individu dalam mengelola tambak dapat beralih menjadi kelompok, karena akan mempermudah memperoleh support dari pemerintah dan mendapatkan keuntungan yang lebih banyak dariapda hanya individu. Pelaksanaan program dilakukan dengan beberapa metode yaitu melakukan sosialisasi pentingnya budidaya menggunakan metode ABG, menjelaskan keuntungan ketika menggunakan metode $\mathrm{ABG}$, pembentukan kader untuk koordinasi antara penyuluh dengan masyarakat agar komunikasi dapat merata, dan pembagian untuk kolam tambak dan job desk masing masing. Serta diadakannya monitoring dan evaluasi, apakah mendapatkan hasil yang lebih efisien ketika menggunakan metode $\mathrm{ABG}$ atau individu. Metode $\mathrm{ABG}$ lebih efisien daripada menggunakan metode individu, diantaranya benur dan pakan dapat dibeli dengan harga yang lebih murah, tebar benur dapat dilakukan bersama-sama sehingga pengawasannya akan lebih mudah, pengelolaan sumber air yang lebih terjaga, dan biosecurity lebih mudah, serta dampak dari pengelolaan menjadi tanggung jawab kelompok bukan individu. Kesimpulan: penggunakaan budidaya dengan metode ABG lebih efisien, mendapatkan harga yang terjangkau ketika membeli benur dan pakan, manajemen penyakit yang dapat dikelola bersama, listrikalisasi yang lebih murah, biosecurity yang lebih mudah dan pengelolaan air yang lebih terjaga (Tandon dan Instalasi Pengolahan Air Limbah).
\end{abstract}

Keyword : Perikanan, budidaya udang, kelompok, berkelanjutan

\begin{abstract}
Indonesia has enormous potential in the field of fisheries, this is because about $70 \%$ of its territory is oceans and archipelagic countries. Shrimp farming in Indonesia is a practice that is widely practiced by Indonesians. This is because shrimp is a fishery commodity that has the highest demand. Aquaculture Base Group (ABG) aims to manage communities, who were originally individuals in managing ponds to become groups, because it will make it easier to get support from the government and get more benefits than only individuals. The program is implemented using several methods, namely socializing the importance of cultivation using the ABG method, explaining the advantages of using the ABG method, forming cadres for coordination between extension agents and the community so that communication can be evenly distributed, and distribution for each pond and job desk. As well as the holding of monitoring and evaluation, whether to get more efficient results when using ABG or individual methods. The ABG method is more efficient than using the individual method, including fry and feed can be purchased at a lower price, fry can be done together so that supervision will be easier, management of water sources is more maintained, and biosecurity is easier, and the impact of management be the responsibility of groups not individuals. Conclusion: the use of $\mathrm{ABG}$ cultivation method is more efficient, get affordable prices when buying fry and feed, disease management that can be managed together, cheaper electricity, easier biosecurity and more maintained water management (Tandon and Waste Water Treatment Plant) .

Keyword : Fishery, shrimp farming, group, sustainable
\end{abstract}




\section{PENDAHULUAN}

Indonesia sebagai negara kepulauan terbesar di dunia memiliki dua pertiga dari wilayah berupa lautan Indonesia yaitu 6,32 juta $\mathrm{km}^{2}$ (Pudjiastuti, 2016), 17.504 pulau-pulau (Pudjiastuti, 2016), dan merupakan salah satu negara yang memiliki garis pantai terpanjang kedua di dunia setelah Kanada yaitu $99.093 \mathrm{~km}^{2}$ (Pudjiastuti, 2016). Secara geografis Indonesia terletak di antara dua benua yaitu Benua Asia dan Benua Australia dan dua samudera yaitu Samudera Hindia dan Samudera Pasifik yang merupakan kawasan paling dinamis dalam percaturan, baik secara ekonomis maupun politik. Letak geografis yang strategis tersebut menjadikan Indonesia memiliki keunggulan serta sekaligus serta ketergantungan yang tinggi terhadap kelautan (Soemarmi \& Diamantina, 2019).

Indonesia memiliki wilayah yang luas dan mendukung untuk pengembangan usaha budidaya udang. Udang merupakan komoditas yang menjadi primadona dalam perikanan, karena dapat meningkatkan devisa negara melalui perdagangan internasional (ekspor) (Utami dkk., 2014). Hal ini dikarenakan udang merupakan salah satu organisme yang memiliki nilai permintaan yang tinggi, salah satu udang yang memiliki tingkat permintaan yang tinggi yaitu udang vaname (Litopenaeus vannamei) (Sa'adah \& Milah, 2019).

Banyak petani di Indonesia yang dulu membudidayakan udang windu beralih menjadi membudidayakan udang vaname. Hal ini dikarenakan udang vaname memiliki beberapa kelebihan salah satunya memiliki tingkat kelulus hidupan yang tinggi, toleran terhadap perubahan lingkungan, mampu memanfaatkan seluruh kolam baik di dasar, kolom maupun permukaan. Selain itu, udang vaname juga merupakan sumber pakan yang memiliki kandungan protein yang tinggi, harganya relatif murah, sehingga dapat menjadi dorongan dalam peningkatan nilai gizi masyarakat Indonesia (Sa'adah \& Milah, 2019)

Udang vaname menjadi komoditas unggulan di Indonesia namun, budidaya udang juga bukanlah hal yang mudah. Hal ini dikarenakan udang rentan sekali terkena penyakit. Penyakit pada udang dapat disebabkan oleh lingkungan maupun secara genetik. Penyebarannya dapat secara horizontal dan vertikal. Penyebaran 
horizontal melalui lingkungan (water treatment), udang yang terinfeksi, pakan yang diberikan dan kotoran udang yang terinfeksi, sedangkan penyebaran secara vertikal yaitu penularan melalui induk ke larvanya (Rahma dkk., 2014). Salah satu penyakit yang menyerang udang umumnya White Feses Disease (WFD), Taura Syndrome Virus (TSV), White Spot Syndrome Virus (WSSV), Yellow Head Virus (YHV), dan Vibriosis.

Strategi dan mekanisme yang efektif membantu pembudidaya ikan skala kecil dalam mengatasi keterbatasan dan tetap kompetitif pada perubahan lingkungan usaha adalah dengan aksi bersama melalui partisipasi dalam kelompok (FAO, 2011). Akuakultur berskala kecil harus dikembangkan secara berkelompok dan pembudidaya ikan sedapat mungkin membentuk kluster (Hermawan et al., 2017) Partisipasi anggota dalam kelompok merupakan unsur utama dalam pencapaian tujuan dan keberlanjutan kegiatan kelompok. Partisipasi aktif dalam kelompok diperlukan karena pembudidaya yang pada akhirnya berperan dalam melaksanakan kegiatan kelompok dan sifat saling ketergantungan antara anggota dengan kelompok (interdependent). Komitmen dan kontribusi masing-masing anggota untuk mencapai tujuan bersama sangat penting bagi keberhasilan dan kelangsungan kegiatan kelompok. Memahami apa yang mendorong perbedaan tingkat partisipasi anggota kelompok menjadi prasyarat penting untuk meningkatkan kinerja kelompok dan pada ujungnya kinerja usaha pembudidaya ikan (Hermawan et al., 2017).

\section{METODE PENELITIAN}

Jenis penelitian menggunakan article review. Desain penelitian digunakan metode retrospektif, prospektif dan tinjauan sistematis. Tinjauan sistematis adalah tinjauan atas pertanyaan yang dirumuskan dengan jelas yang menggunakan metode sistematis dan eksplisit untuk mengidentifikasi, memilih, dan menilai secara kritis penelitian yang relevan, dan untuk mengumpulkan dan menganalisis data dari studi yang termasuk dalam tinjauan (Vardavas \& Nikitara, 2020). Artikel yang digunakan adalah artikel jurnal internasional dan nasional yang ditelusuri menggunakan beberapa database online: 1) Pubmed, 
2) Science Direct, 3) Google Scholar. Pencarian sumber referensi atau literatur dimulai pada 01 April - 14 April 2020. Kata kunci yang digunakan dalam pencarian istilah: Aquaculture Base Group, perikanan, aquaculture, budidaya udang, benur dan kelompok budidaya perikanan, serta artikel pendukung lannya. Studi dimasukkan jika ada: 1) studi 10 tahun keatas; 2) diterbitkan dalam bahasa Inggris atau Indonesia.

\section{HASIL DAN PEMBAHASAN}

Indonesia merupakan salah satu wilayah negara yang diakui secara hukum oleh negara-negara di dunia dengan luas wilayah $1 / 3$ adalah lautan (Bappenas, 2019). Sehingga, Indonesia dikenal sebagai negara kelautan atau negara bahari yangmana hampir seluruh masyarakat Indonesia yang bertempat tinggal di tepi pantai memupukkan harapan keberlangsungan hidupnya pada sektor perikanan (Soemarmi \& Diamantina, 2019). Salah satu usaha yang digeluti masyarakat pesisir selain mencari ikan dilaut atau sebagai nelayan, mereka melakukan usaha tambak ikan, udang, lobster dan banyak lagi jenis budidaya perikanan lainnya (Tjahjaningsih, 2020). Budaya yang sering diterapkan pada masyarakat pembudidaya biasanya menerapkan sistem individualis budidaya (Fauzi et al., 2007; T. Utami, 2019). Sehingga, tak jarang beberapa lahan tambak dikuasai oleh satu orang saja. Sedangkan, nelayan lainnya bekerja secara informal pada pemilik tambak (Fauzi et al., 2007).

Sistem budidaya perorangan atau mandiri pada satu orang memiliki beberapa kelemahan secara struktural, manajemen, keuangan dan loss/profit. Hal tersebut akan terjadi apabila pemilik lahan tambak tidak bisa memanajemen dengan baik, maka kerugian akan menjadi hasil akhir. Kelemahan yang terjadi apabila pemilik tambak rugi maka harus menanggungnya secara individu, dikarenakan nelayan yang lainnya hanya bekerja secara informal (Prabowo, 2019). Kerugian yang dialami para pemilik tambak tidak hanya diakibatkan oleh faktor internal namun ada beberapa faktor eksternal yang mendasarinya di antaranya adalah harga pakan akan lebih mahal jika membeli dalam jumlah kecil, pengelolaan air tambak memerlukan biaya yang mahal (limbah yang dikeluarkan dapat mengakibatkan 
dampak buruk pada lingkungan jika tidak dikelola dengan baik) (Ahmad Rido'i Yuda Prayogi, Tualeka, et al., 2020), sistem tebar benih yang tidak merata dapat mengakibatkan penyakit pada benih, pembelian benih dalam jumlah kecil lebih mahal dan masih banyak lagi faktor penyebabnya (Prabowo, 2019). Adanya kerugian pada pemilik tambak dapat menyebabkan gangguan kesehatan seperti depresi, hal ini dikarenakan timbulnya suatu kebiasaan yang berbeda dapat menyebabkan penurunan fungsi kesehatan mental (Prayogi, Hardini, et al., 2020).

Salah satu bidang perikanan yang ramai dikelola oleh para pemilik tambak adalah udang (Haliman \& S, 2019). Hal tersebut dikarenakan udang vaname menjadi komoditas unggulan di Indonesia namun, budidaya udang juga bukanlah hal yang mudah (Soebjakto, 2020). Hal ini dikarenakan udang rentan sekali terkena penyakit. Penyakit pada udang dapat disebabkan oleh lingkungan maupun secara genetik (Sa'adah \& Milah, 2019). Selain itu, udang vaname memiliki beberapa kelebihan salah satunya memiliki tingkat kelulus hidupan yang tinggi (Rahma dkk., 2014). Namun, kembali lagi ke permasalahannya jika dilakukan secara perorangan, dampak terjadinya kerugian atau kegagalan produksi lebih besar, sehingga peneliti memiliki gagasan untuk menciptakan adanya Aquaculture Base Group (ABG) bertujuan untuk memanajemen masyarakat yang semulanya individu dalam mengelola tambak dapat beralih menjadi kelompok, karena akan mempermudah memperoleh support dari pemerintah dan mendapatkan keuntungan yang lebih banyak dariapda hanya individu. Adanya pembentukan kelompok menjadi salah satu pemberdayaan yang dapat dilakukan untuk memaksimalkan potensi yang ada di masyarakat (Kuswanti, 2017).

Tahapan pelaksanaan program ini diataranya dimulai dari sosialisasi pentingnya budidaya menggunakan metode ABG, pembentukan kader, pembagian kolam tambak dan job desk, serta monitoring dan evaluasi. Tahap pertama yaitu dilakukan sosialisasi pelaksanaan program $\mathrm{ABG}$ terhadap nelayan pemilik tambak di beberapa wilayah kabupaten Banyuwangi. Tahap ini peneliti bekerja sama dengan pemerintah desa untuk melaksanakan program ini agar bias berjalan lebih baik. Pada tahap pertama ini kami 
melakukan sosialisasi terkait bagaimana sistem program $\mathrm{ABG}$, manfaat dan kelebihan, proses pelaksanaan program dan sistem budidaya ABG. Sosialisasi diyakini menjadi sebuah awal yang penting, dikarenakan seseorang akan merasa mudah memahami ketika sudah mendapatkan penjelasan (Fatmawati, 2019; Lindriati, 2019).

Tahap kedua melaksanakan pembentukan kader, hal ini dilakukan supaya koordinasi dan komunikasi antara penyuluh dengan masyarakat terlaksana dengan merata. Pelaksanaan pada tahap kedua dilaksanakan setelah sosialisasi, sehingga tidak memerlukan pengumpulan nelayan kembali dan dilaksanakan pada hari yang sama. Kader berfungsi untuk mempermudah pengelolaan tambak dan akan lebih mudah menerima bantuan dari pemerintah jika sudah berrbentuk kelompok. Kader merupakan kelompok-kelompok petambak yang akan terbagi dalam beberapa lokasi. Penentuan kelompok kader disesuaikan dengan lokasi tambak yang saling berdekatan. Sehingga, akan mempermudah untuk melakukan perawatan dan koordinasi. Jumlah kader dalam kelompok disesuaika dengan jumlah tambak.
Tahap ketiga yaitu pembagian kolam dan job desk. Masing-masing kader dalam kelompok akan diberi bagian dan job desk sesuai dengan kesepakatan kelompok. Beberapa bagian yang diperlukan dalam kelompok yaitu pengelolaan air dan produksi. Pembagian bagian pada masing-masing kader diharapkan dapat memupukkan tanggung jawab pada kader dan rasa kepemilikan akan meningkat.

Tahap terakhir yaitu monitoring dan evaluasi. Tahap monitoring dan evaluasi dilakukan setiap kali produksi sekitar 3 hingga 4 bulan, sehingga dalam satu tahun diperkirakan akan melakukan monitoring dan evaluasi sebanyak 3 kali. Pembahasan yang dilakukan pada monitoring dan evaluasi adalah terkait kendala dan progress selama produksi, serta pemberian wawasan tambahan untuk meningkatkan produksi udang vaname. Diharapkan dengan adanya program ini dapat meningkatkan perekonomian masyarakat pantai khususnya para petani tambak udang.

Manfaat Penelitian :

1. Pengelolaan pakan menjadi lebih mudah dan dapat 
mendapatkan omset banyak

dibandingkan sendirian

2. Benur dapat dibeli menggunakan harga yang lebih terjangkau apabila dilakukan secara kelompok

3. Pengawasan akan lebih mudah ketika penebaran dilakukan secara bersama-sama

4. Pengelolaan sumber air yang lebih optimal

5. Dampak positif atau negatuf dari pengelolaan ditanggung kelompok, sehingga tidak mengalami kerugian yang besar

6. Listrikisasi dan biosecurity lebih mudah

Luaran penelitian ini dapat menjadikan pembudidaya di banyuwangi lebih maju dan lebih mudah dalam meminta support dari pemerintah, karena pemerintah akan memberikan fasilitas dalam bentuk kelompok, bukan individu (Agus, 2021). Sehingga, dapat memperoleh hasil yang lebih maksimal dengan dilakukan secara berkelompok.

\section{KESIMPULAN}

Penggunakaan budidaya dengan metode ABG lebih efisien, mendapatkan harga yang terjangkau ketika membeli benur dan pakan, manajemen penyakit yang dapat dikelola bersama, listrikalisasi yang lebih murah, biosecurity yang lebih mudah dan pengelolaan air yang lebih terjaga (Tandon dan Instalasi Pengolahan Air Limbah). Diharapkan dengan adanya program ABG kesejahteraan petani tambak udang akan meningkat.

\section{Ucapan Terima Kasih}

Ucapan terimakasih kepada Allah SWT yang telah melimpahkan keberkahannya sehingga terciptanya karya tuis ini. Tidak lupa juga ucapan terimakasih kepada Fakultas Perikanan dan Kelautan, Fakultas Kesehatan Masyarakat, dosen dan semua pihak yang sudah membantu dalam pembentukan karya tulis ini.

\section{DAFTAR PUSTAKA}

Agus. (2021). Pelatihan BP3. Jala Tech: Banyuwangi

Bappenas. (2019). Rancangan Teknokratik Rencana Pembangunan Jangka Menengah Nasional 2020 - 2024: Indonesia Berpenghasilan Menengah - Tinggi Yang Sejahtera, Adil, dan Berkesinambungan. Kementerian PPN/ Bappenas, 313. https://doi.org/10.1017/CBO97811074153 24.004

Fatmawati, F. (2019). Meningkatkan Pemahaman Masyarakat dalam Sosialisasi Bahaya Cemaran Logam Berat Pada Kosmetik. Jurnal Pemikiran Agama Dan Pemberdayaan, $\quad$ 19(1), 73-84. 
Journal of Aquaculture Science

DOI: https://doi.org/10.31093/joas.v6i1IS.155

https://jurnal.unimed.ac.id/2012/index.php/ jkss/article/view/8771

Fauzi, A., Haluan, J., \& Boer, M. (2007). Di Provinsi Nanggroe Aceh Darussalam ( NAD ) 1. Jurnal Ilmu-Ilmu Perairan Dan Perikanan Indonesia, 14(1), 73-80.

Haliman, R. W., \& S, D. A. (2019). Udang Vanname. Jurnal Ilmu-Ilmu Agribisnis, 7(979-484), 74-75.

Hermawan, A., Amanah, S., \& Fatchiya, A. (2017). Partisipasi Pembudidaya Ikan dalam Kelompok Usaha Akuakultur di Kabupaten Tasikmalaya. Jurnal Penyuluhan, 13(1), 1. https://doi.org/10.25015/penyuluhan.v13i1 .12903

Kuswanti, I. D. (2017). Peran pengurus kelompok tani tambak "tirta anugrah" bagi pemberdayaan ekonomi anggota di dusun ngentak poncosari srandakan bantul ringkasan skripsi. Universitas Negeri Jogjakarta.

Lindriati, S. (2019). Pengaruh Sosialisasi Dan Tingkat Pemahaman Masyarakat Terhadap Minat Pembuatan Akta Kematian Di Desa Purworejo. FAKULTAS KEGURUAN DAN ILMU PENDIDIKAN, Universitas Lampung, 53(9), 1689-1699.

Prabowo, R. G. M. (2019). Manajemen Strategi. https://doi.org/10.31227/osf.io/xu37y

Prayogi, Ahmad Rido'i Yuda, Hardini, P. P., Alamiyyah, M., Indah, K. S., Haqi, D. N., \& Sari, J. D. E. (2020). Determining Of Student Depression Level In The Covid-19 Pandemic Period (Case Study Of Airlangga University Students, Surabaya). Journal of Community Mental Health and Public Policy, 4(1), 1-7.

Prayogi, Ahmad Rido'i Yuda, Tualeka, A. R., Ahsan, A., Rahmawati, P., Russeng, S. S., \& Susilowati, I. H. (2020). The Determination of Safe Concentration of Non-Carcinogenic Toluene in Surabaya Printing. The Indonesian Journal Of Occupational Safety and Health, 9(3), 360. https://doi.org/10.20473/ijosh.v9i3.2020.3 60-368

Rahma, H. N., Prayitno, S. B., \& Haditomo, A. H. C. (2014). Infeksi White Spot Syndrom Virus (Wssv) Pada Udang Windu (Penaeus Monodon Fabr.) Yang Dipelihara Pada Salinitas Media Yang Berbeda. Journal of
July 2021 Vol 6 Issue Spesial: 44-51

Online pada http://joas.co.id

Aquaculture Management and Technology, 3(3), 25-34.

Sa'adah, W., \& Milah, K. (2019). Permintaan Udang Vannamei (Litopenaeus Vannamei ) Di Kelompok Pembudidaya Udang AtTaqwa Paciran Lamongan. Jurnal Pemikiran Masyarakat Ilmiah Berwawasan Agribisnis, 5(2), 243-251.

Soebjakto, S. (2020). Strategi pengembangan bisnis budidaya udang. Kementerian Kelautan Dan Perikanan.

Soemarmi, A., \& Diamantina, A. (2019). Konsep Negara Kepulauan Dalam Upaya Perlindungan Wilayah Pengelolaan Perikanan Indonesia. Masalah-Masalah Hukum, 48(3), 241. https://doi.org/10.14710/mmh.48.3.2019.2 41-248

Tjahjaningsih, W. (2020). Menggelorakan Pariwisata Bahari Di Daerah 3T. Fakultas Perikanan Dan Kelautan Universitas Airlangga.

Utami, R., Supriana, T., \& Ginting, R. (2014). Analisis faktor-faktor yang mempengaruhi produksi tambak udang sistem ekstensif dan sistem intensif. Journal of Agriculture and Agribusiness Socioeconomics, 3(2), 110 .

Utami, T. (2019). Pemberdayaan Komunitas Sektor Informal Pedagang Kaki Lima (Pkl), Suatu Alternatif. Journal Sosiologi, 25(2), 114-123.

Vardavas, C. I., \& Nikitara, K. (2020). COVID19 and smoking: A systematic review of the evidence. In Tobacco Induced Diseases (Vol. 18, Issue March, pp. 1-4). https://doi.org/10.18332/tid/1 